\title{
INOVASI PENGELOLAAN KEHANDALAN WAKTU PERJALANAN (TRAVEL TIME RELIABILITY)
}

\author{
Noni Paisah ${ }^{1)}$ \\ Staf Pengajar pada Fakultas Teknik, Universitas Graha Nusantara \\ Jalan Dr. Sutomo Padang Sidimpuan Telp. (0634) 25292 Fax (0634) 28327. Kode Pos 22719
}

Email:dumasarilumongga@yahoo.com

\begin{abstract}
Time management is an important way to support the activities of individuals every day. Disorders of the trip cause variety of problems that might impact on the delay in achieving performance and productivity optimal. To that end, each individual since the beginning to need adoption of the management methods innovation to implement the travel time reliability. This method has real value to help the use of a more appropriate time to reach the destination.
\end{abstract}

Keywords: innovation, management, travel time reliability

\section{PENDAHULUAN}

Transportasi

berfungsi untuk memperlancar gerak roda perekonomian, memperkokoh persatuan dan kesatuan serta membebaskan masyarakat dari keterisoliran dan keterpencilan. Oleh karena itu, fungsi transportasi bukan hanya sebagai unsur penunjang namun juga menjadi unsur pelancar pembangunan nasional.

Fungsi transportasi sebagai unsur penunjang terealisasi ketika sektor ini secara langsung dan riil menyediakan jasa perhubungan yang efektif untuk memenuhi kebutuhan berbagai sektor lain dalam pembangunan nasional. Transportasi berfungsi memberi kemudahan bagi setiap individu dalam menjalankan aktivitas keseharian hingga menunjang pencapaian kinerja dan produktivitas lebih optimal.

Sebagai unsur pelancar, fungsi transportasi mampu mempercepat akses dan mobilitas pelaksanaan pembangunan nasional di berbagai wilayah. Dengan prasarana dan sarana transportasi yang layak, daya jangkau masyarakat terhadap berbagai kesempatan kerja, usaha produktif dan program pembangunan tentu makin meningkat.

Salah satu fasilitas prasarana transportasi yang urgen diperhatikan dari waktu ke waktu ialah jalan. Fasilitas jalan selalu dibutuhkan masyarakat untuk dapat bergerak dari satu tempat ke tempat lain guna melaksanakan aktivitas sehari-hari. Keberadaan dan kelayakan jalan turut serta menentukan ketepatan waktu perjalanan yang dibutuhkan ketika hendak mencapai lokasi tujuan tertentu. Berdasarkan hasil penelitian Ryu, et al., (2011) diketahui bahwa ketepatan waktu perjalanan ditentukan antara lain oleh sistem transportasi termasuk konstruksi dan pemeliharaan jalan serta sistem kontrol lalu lintas.

Para pengguna jasa jalan menghadapi sederet permasalahan terutama dalam hal memperoleh ketepatan waktu perjalanandalam perjalanan. Masalah kemacetan hampir setiap hari terjadi di berbagai ruas jalan perkotaan (Federal Highway Administration, 2006). 
Permasalahan penggunaan prasarana dan sarana jalan yang tidak memadai ternyata tidak hanya mengakibatkan pengguna jasa terkena ketidaktepatan dalam hal pencapaian waktu perjalanan. Namun juga rawan memicu terjadi peristiwa kecelakaan lalu lintas, keterlambatan masuk kerja hingga terkena sanksi yang berlaku dan peristiwa lain yang tidak diharapkan. berlaku.

Permasalahan dalam pengelolaan waktu perjalanan dari rumah ke lokasi tujuan (kerja) yang masih kurang teratur seringkali mengakibatkan keterlambatan dan ketertundaan kinerja dan produktivitas. Salah satu alternatif solusi yang dapat dikedepankan guna menyelesaikan berbagai jenis dari permasalahan jalan sebagai bagian sistem transportasi darat khususnya untuk membantu para pengguna jasa mendapatkan ukuran waktu perjalanan yang lebih tepat dan perlu dikembangkan ialah pemanfaatan inovasi metode kehandalan waktu perjalanan (travel time reliability).

\section{Pemanfaaatan Kehandalan Waktu Perjalanan}

Sistem transportasi umum yang handal merupakan suatu modal bagi perekonomian nasional yang urgen dan krusial diperhatikan berbagai pihak terkait. Setiap jaringan transportasi umum memiliki fungsi yang sangat berarti bagi pemberian kesempatan anggota masyarakat melakukan mobilitas dari berbagai lokasi asal ke lokasi tujuan. Oleh karena itu, menurut penjelasan Susilowati, et al., (2010) diketahui bahwa sistem transportasi menjadi salah satu parameter dalam mengevaluasi keberhasilan pelaksanaan pembangunan nasional.

Pemanfaatan sistem transportasi umum yang efektif terutama fasilitas jalan membutuhkan perencanaan yang matang dan sistematis. Perencanaan tidak hanya perlu dilakukan oleh pengembang teknis konstruksi jalan namun juga perlu diperhatikan para pengguna jasa yang melakukan perjalanan dari satu lokasi ke lokasi lain untuk kepentingan berbagai aktivitas kehidupan. Kemampuan setiap pengguna jasa jalan dalam mengatur waktu dan rute perjalanan senantiasa penting disesuaikan dengan kondisi kelayakan fasilitas jalan yang ditempuh. Kondisi fasilitas jalan yang dimaksud mencakup: panjang jalan, lebar ruas jalan, kapasitas jalan, volume dan kepadatan lalu lintas, sistem kontrol lalu lintas serta kelayakan, kontruksi jalan.

Fasilitas kelayakan jalan tidak selalu memberikan pelayanan yang memuaskan bagi para pengguna jasa. Sederet permasalahan dalam pemanfaatan jaringan prasarana dan sarana jalan ditemukan setiap hari khususnya di wilayah perkotaan. Salah satu permasalahan jalan yang masih sulit diselesaikan terkait dengan kemacetan lalu lintas. Permasalahan ini muncul karena berbagai hal seperti: peningkatan jumlah penduduk kota, peningkatan jumlah kendaraan, keterbatasan ruas jalan yang sempit, kerusakan jalan dan lainnya. Dengan adanya ragam permasalahan dalam penggunaan jalan mengakibatkan berbagai risiko yang tidak dikenhendaki para pengguna jalan seperti: ketertundaan waktu perjalanan. Risiko ketertundaan waktu perjalanan menimbulkan berbagai dampak penting bagi kelancaran aktivitas pengguna jasa jasa baik di bidang usaha produktif maupun non produktif.

Pengalaman dalam perjalanan yang sering tertunda oleh permasalahan fasilitas jalan yang tidak memadai mengakibatkan pengguna jasa jalan perlu menerapkan metode kehandalan waktu perjalanan (travel time reliability). Merode ini memberikan manfaat yang berharga bagi para pengguna jasa jalan agar terhindar dari sederet permasalahan yang tidak diharapkan. Menurut hasil penelitian Chen, et al., (2003) dibuktikan bahwa pemanfaatan kehandalan waktu perjalanan memang memiliki kebermanfaatan guna memperlancar pelayanan fasilitas prasarana dan sarana jalan bagi setiap pengguna baik pengemudi kendaraan umum, pengemudi kendaraan pribadi, pejalan kaki dan lainnya.

Kehandalan waktu perjalanan dapat diartikan sebagai tingkat konsistensi atau 
frekuensi jumlah variasi waktu perjalanan dengan beberapa kali pengukuran. Jika semakin besar variasi yang ada, maka semakin inkonsisten waktu perjalanan atau semakin buruk kadar kehandalan waktu perjalanannya. Sebaliknya, bila semakin kecil variasi waktu perjalanan maka kian konsistensi waktu perjalanan yang ditempuh.

Salah satu kemanfaatan dari penerapan kehandalan waktu perjalanan ialah para pengguna jasa jalan mampu meramalkan waktu tempuh dari lokasi pemberangkatan menuju ke lokasi tujuan lebih akurat hingga pada gilirannya tercegah dari permasalahan ketertundaan, keterlambatan dan peristiwa lain yang merugikan kinerja dan produktivitas. Kehandalan waktu perjalanan sangat bermanfaat bagi pengguna jasa jalan. Hal ini dikarenakan ketika merencanakan mobilitas sejak awal sudah dapat mengetahui curah waktu tempuh yang dijalani.

Pemanfaatan kehandalan waktu tempuh juga mampu meningkatkan daya produksi usaha, penyebaran produk yang lebih merata dan tepat waktu sampai kepada konsumen dan menaikkan kinerja para pegawai pada berbagai instansi pemerintah dan swasta $\mathrm{Di}$ samping itu, Recker, et all., (2005) mengemukakan bahwa pemahaman yang baik mengenai kehandalan waktu perjalanan membantu pihak perencana sistem transportasi umum agar makin bijaksana dalam memutuskan ragam kebijakan yang lebih tepat guna untuk mereduksi permasalahan kemacetan dan dampak insiden lain. Dengan demikian, semakin disadari fungsi kehandalam waktu perjalanan memang penting karena merupakan metode yang efektif bagi para ragam pihak dalam upaya optimalisasi fungsi pelayanan jasa sistem transportasi umum termasuk fasilitas prasarana dan sarana jalan. Pemanfaatan kehandalan waktu perjalanan dalam aktivitas mobilittas memerlukan perencanaan dan keputusan matang yang dikelola secara rasional dan profesional dalam pola manajemen tertentu.

\section{Ragam Faktor Penentu Keandalam Waktu Perjalanan}

Realitas sosial menunjukkan hampir semua pihak yang sedang melakukan perjalanan berkeinginan agar sampai ke tujuan dengan tepat waktu. Hanya saja, keinginan yang diharapkan oleh semua pihak ini cenderung dilakukan dalam selang waktu yang relatif bersamaan. Sebagai konsekwensi, orang yang melakukan perjalanan di berbagai ruas jalan senantiasa menghadapi terjadinya keramaian dan kemacetan lalu lintas. Tidak dapat dihindari, pada rentang waktu tertentu di jalan berlangsung jam puncak, yang menunjukkan tingkat kemacetan tertinggi hingga seringkali mengakibatkan permasalahan ketertundaan atau keterlambatan menuju ke lokasi tujuan. Hampir semua pihak yang mengalami permasalahan kemacetan dan ketertundaan atau keterlambatan mengalami strees selama perjalanan karena kecemasan yang tertumpuk berulang kali tidak dapat tiba di lokasi tujuan dengan tepat waktu. Beberapa orang yang menghadapi permasalahan ini juga rawan terkena berbagai gangguan yang menyulitkan bagi pegawai, penyedia jasa layanan publikdan lainnya. Hasil penelitian Small, et al., (1999) menunjukkan bahwa setiap orang yang tengah menembpuh perjalanan termasuk pihak yang bertugas mengangkut ragam jenis ragam paling tidak menyukai penjadwalan yang tidak tepat sampai tujuan. Berbagai pihak tersebut sampai ada yang berani mengeluarkan sejumlah premi sebagai biaya insentif menghindari permasalahan kemacetan dan ketertundaan atau keterlambatan. Pembayaran premi juga ditujukan untuk memperoleh Kehandalan waktu perjalanan yang lebih besar.

Beberapa faktor yang menentukan perlunya pemanfaatan Kehandalan waktu perjalanan ialah pengalaman buruk berlalu lintas dan kesadaran risiko/dampak akibat permasalahan kemacetan, ketertundaan atau keterlambatan. Pengalaman buruk sewaktu para pengguna jasa jalan melakukan perjalanan dengan motif berbagai 
kepentingan sangat bisa terekam dalam ingatan hingga sering berupaya menghindarinya sedini mungkin. Demikian juga kesadaran atas risiko atau dampak yang diterima ketika harus tertunda atau terlambat menuntut para pengguna jasa jalan mengambil keputusan dari berbagai alternatif yang memberi kesempatan tiba di lokasi tujuan lebih tepat waktu.

Para pengguna jasa jalan kurang mentolerir terhadap masalah ketertundaan atau keterlambatan yang tidak terduga (unexpected delays) disebabkan konsekuensi yang lebih besar dibandingkan dengan kemacetan tiap hari yang dialami. Berdasarkan Laporan Federal Highway Administration (2006) terdapat gambaran kondisi lalu lintas yang dialami para pengguna jasa jalan dengan variasi waktu tempuh dari hari ke hari seperti terlihat pada Gambar 1.

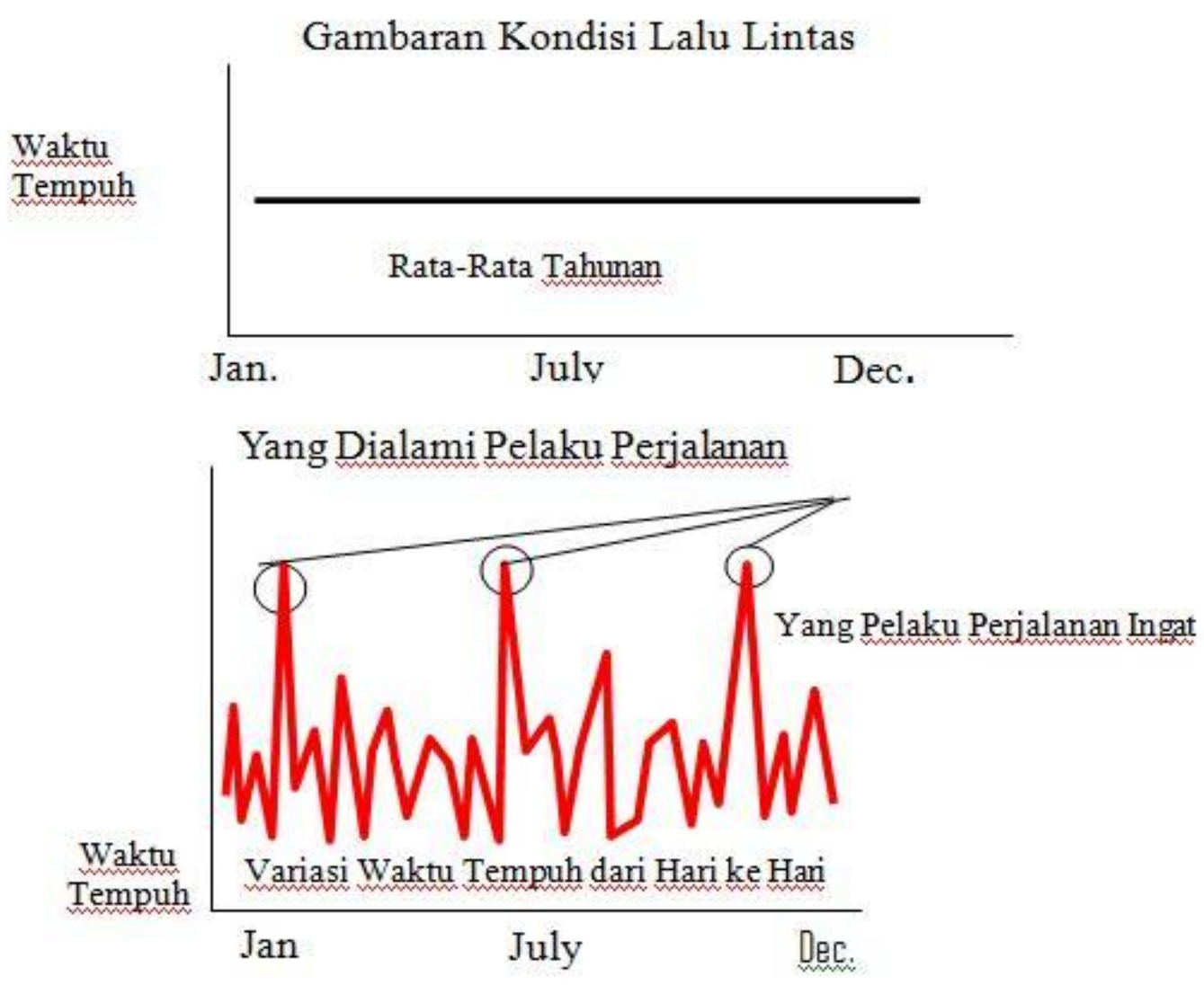

Gambar 1. Gambaran Kondisi Lalu Lintas yang Dialami Pelaku Perjalanan dengan Variasi Waktu Tempuh dari Hari ke Hari

Sumber : Federal Highway Administration (2006)

Kondisi lalu lintas yang teramati pada Gambar 1 secara jelas menunjukkan adanya ancaman ketertundaan atau keterlambatan yang sewaktu-waktu menimpa para pengguna jasa jalan. Guna menghindari segala permasalahan lalu lintas yang berkaitan dengan terutama kemacetan, para pengguna jasa jalan yang bergerak dari satu lokasi asal ke lokasi tujuan pada rute tertentu penting memanfaatkan kehandalan waktu perjalanan. Pengukura perbedaan rentang waktu tiba dari beberapa kali perjalanan antara sebelum dan sesudah memanfaatkan travel time reliability melalui pengambilan keuntungan aras pengelolaan lalu lintas dapat eramati pada Gambar 2. 


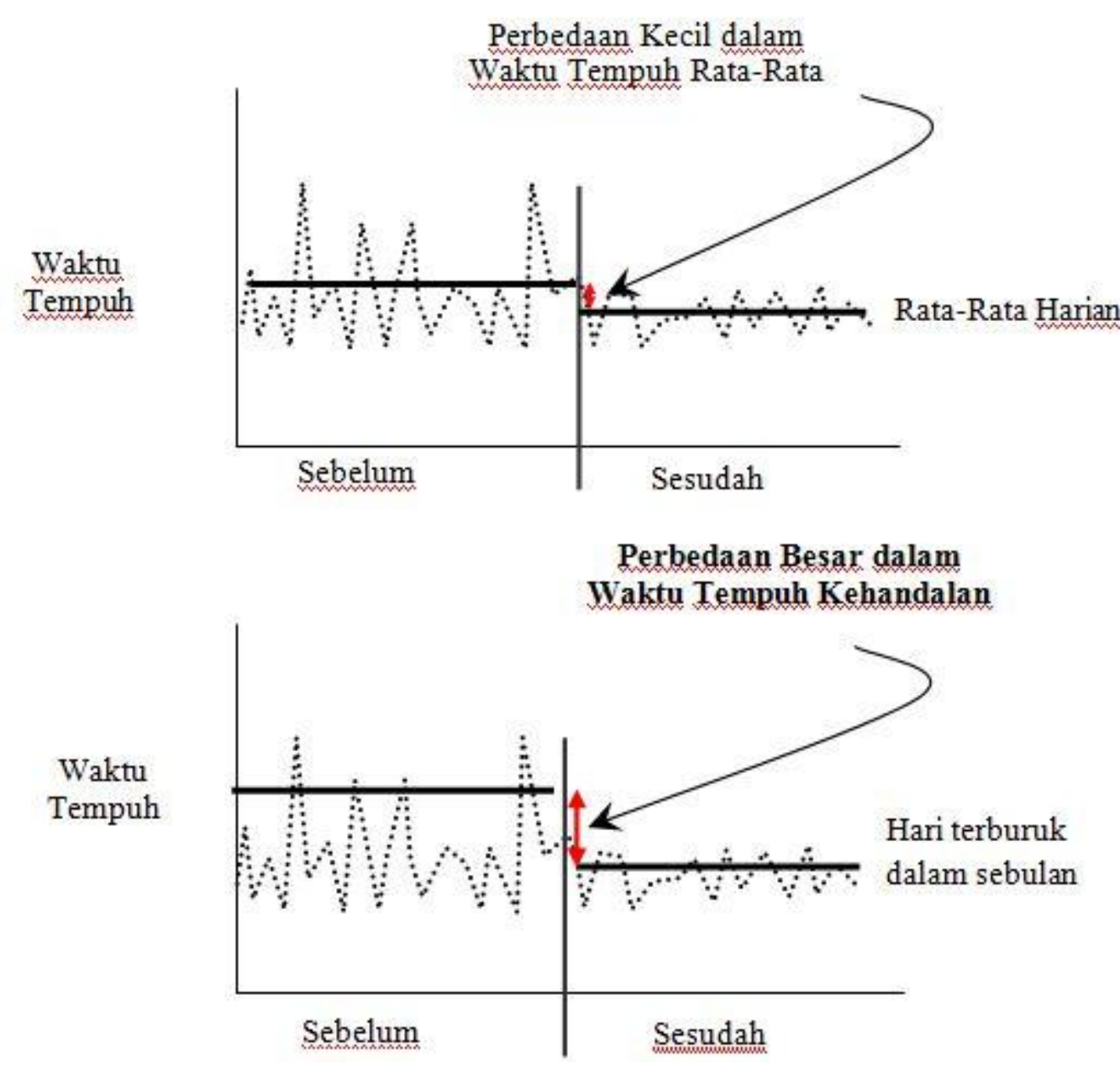

Gambar 2. Pengukuran Kehandalan Waktu Perjalanan dalam Pengambilan Keuntungan dari Pengelolaan Lalu Lintas

Sumber : Federal Highway Administration (2006)

\section{Ukuran Kehandalan Waktu Perjalanan}

Kehandalan waktu perjalanan pada prinsipnya dapat diartikan sebagai kisaran waktu tempuh perjalanan yang dialami para pengguna jasa jalan dalam melaksanakan sejumlah mobilitas sehari-hari dengan dibekali terjaminan waktu tiba yang lebih tepat sampai di lokasi tujuan tertentu. Walaupun demikian, perlu diperhatikan rentang waktu tempuh yang dijalani dengan sistem kehandalan menjadi tidak bernilai penting ketika tidak dilakukan upaya membandingkan berbagai kondisi dan fasilitas serupa untuk mengatur penjadwalan waktu tiba secara lebih tepat.

Menurut penjelasan Ikhrate and Michell (1997), Kehandalan dapat dinyakan sebagai kesempatan yang memiliki peluang besar sampai di tempat tujuan dalam waktu tempuh perjalanan yang lebih tepat sesuai dengan yang telah diperkirakan. Lomax, et al., (2001) telah mengemukakan bahwa kehandalan adalah indikator yang menunjukkan perbedaan dalam setiap kejadian keterlambatan/ tertundanya perjalanan yang dialami individu pada keseharian dengan atau tanpa terjadinya insiden yang merugikan bagi pencapaian tujuan.

Kedua hasil pemikiran di atas memberikan pemahaman mengenai perlunya kejelasan ukuran kehandalan waktu selama menempuh perjalanan tidak mempertimbangkan unsur ketertundaan atau keterlambatan yang berlangsung berulang kali. Selain itu, gambaran refleksi variasi waktu tempuh juga 
terabaikan. Padahal menurut hasil penelitian Ryu, et al., (2011) diketahui ukuran (standar) reliabilitas sebaiknya mampu untuk merefleksikan baik varian waktu tempuh perjalanan dan penerimaannya oleh para pengguna. la menguraikan lebih lanjut tentang level (tingkat) agregat yang berbeda (misalnya segment jalan, koridor, jaringan dan lain-lain ternyata membutuhkan berbagai ukuran (standar) kehandalan yang berbeda.
Dengan mempertimbangkan pemikiran Lomax, et all., (2003) and Lint, et all., (2008) pada akhirnya Ryu (2011) menjelaskan beberapa ukuran kehandalan waktu perjalanan yang penting diperhatikan oleh berbagai pihak pengguna jasa jalan. Ragam ukuran dan metode perhitungan Kehandalan waktu perjalanan yang dimaksud yang dimaksud tertera pada Tabel 1.

Tabel 1. Ukuran dan Metode Perhitungan Kehandalan Waktu Perjalanan

\begin{tabular}{|c|c|c|}
\hline Category & Name & Formula \\
\hline \multirow{3}{*}{$\begin{array}{l}\text { Statistical } \\
\text { Range }\end{array}$} & $\begin{array}{l}\text { Travel Time } \\
\text { Window }\end{array}$ & average travel time \pm standard deviation \\
\hline & $\begin{array}{l}\text { Percent } \\
\text { Variation }\end{array}$ & $\frac{\text { standard deviation }}{\text { average travel time }} \times 100$ \\
\hline & $\begin{array}{l}\text { Variability } \\
\text { Indeks }\end{array}$ & $\frac{\text { difference in peak - period confidence interval }}{\text { difference in off - peak-period confidence interval }}$ \\
\hline \multirow{3}{*}{$\begin{array}{l}\text { Buffer time } \\
\text { measures }\end{array}$} & Buffer Time & $95^{\text {th }}$ percent travel time - average travel time \\
\hline & Buffer Indeks & $\frac{\left(95^{\text {th }} \text { percent travel time }- \text { average travel time }\right)}{\text { average travel time }} \times 100$ \\
\hline & $\begin{array}{l}\text { Planning } \\
\text { Time Indeks }\end{array}$ & $95^{\text {th }}$ percentile travel time indeks \\
\hline \multirow{4}{*}{$\begin{array}{l}\text { Tardy Trip } \\
\text { Indicators }\end{array}$} & $\begin{array}{l}\text { Florida } \\
\text { Realibility } \\
\text { Indeks }\end{array}$ & $100 \%$ - (percent of trips with travel times greater than expected) \\
\hline & $\begin{array}{l}\text { On time } \\
\text { arrival }\end{array}$ & $\begin{array}{l}100 \% \text { - (percent of travel rates greater than } 110 \% \text { of the average travel } \\
\text { rate) }\end{array}$ \\
\hline & \multirow{2}{*}{$\begin{array}{l}\text { Misery } \\
\text { Indeks }\end{array}$} & $\begin{array}{l}\text { (average ofthe travel rates for the longest } 20 \% \text { of the trips } \\
\qquad- \text { average travel rates for all trips) }\end{array}$ \\
\hline & & average travel rate \\
\hline Probabilistic & Probabilistic & $\operatorname{Pr}($ travel time $>\alpha$.travel time threshold $)$ \\
\hline \multirow{3}{*}{$\begin{array}{l}\text { Skew and } \\
\text { width } \\
\text { measures }\end{array}$} & $\lambda^{\mathrm{var}}$ & $\frac{\left(90^{\text {th }} \text { percentile travel time }-10^{\text {th }} \text { percentile travel time }\right.}{(50 \text { th percentile travel time })}$ \\
\hline & $\lambda^{\text {skew }}$ & $\frac{\left(90^{\text {th }} \text { percentile travel time }-50^{\text {th }} \text { percentile travel time }\right.}{\left(50^{\text {th }} \text { percentile travel time }-10^{\text {th }} \text { percentile travel time }\right)}$ \\
\hline & $\mathrm{UI}_{\mathrm{r}}$ & $\frac{\lambda^{\mathrm{var}} \ln \left(\lambda^{\text {skew }}\right)}{\text { travel time per unit length }}$ \\
\hline
\end{tabular}

Sumber : Lomax, et all., (2003) and Lint, et all., (2008) dalam Ryu, et all., (2011)

\section{Kesimpulan dan Saran}

Pengelolaan kehandalan waktu perjalanan mwempunyai nilai penting dalam meningkatkan kesempatan untuk mencapai kinerja dan produktivitas lebih optimal. Berbagai faktor turut mempengaruhi kehandalan waktu perjalanan sejak dari lokasi keberangkatan sampai ke tujuan. Inovasi 225 pengelolaan kehandalan waktu perjalanan memerlukan berbagai ukuran yang perlu diperhatikan berbagai pihak. Pengelolaan keterhandalan waktu perjalanan dapat bermanfaat membantu individu terhindar dari beberapa kejadian yang merugikan seperti keterlambatan/ketertundaan mencapai tujuan tertentu, kegagalan kerjasama, risiko 
kekecewaan pihak lain yang terlalu lama menunggu dan lainnya.

\section{DAFTAR PUSTAKA}

Chen, Chao. Alexander Skabardonis and Pravin Varaiya. 2003. Travel Time Reliabilility as a Measure of Service. Chaos@eecs.barkeley.edu.

Federal Highway Administration (FHA). 2006. Travel Time Reliability: Making It There On Time, All The Time. Federal Highway Administration (http://ops.fhwa.dot.gov);

http://ops.fhwa.dot.gov/publications/tt_reliability/in dex.htm.

Ikhrata, H., and P., Michell. 1998. Technical Report of Southern California Association of Governments' Transportation Performance Indicators, Journal of the Transportation Research Board, Nomor 1606, TRB, National Research Council. Washington, D.C.

Lomax, T., Turner, S., and Margiotta, R., $200 \mathrm{I}$. Monitoring Urban Roadways in 2000: Using Archived Operations Data for Reliability and Mobility Measurement. Federal Highway Administration-Operations Core Business Unit, FHWA-OP-02-029

Recker, W., Chung, Y., Taman, J., Wang, L., Chen, A., Ji, Z., Liu, H., Horrocks, M. and Oh, J. S., 2005. Considering Taking Risk Behavior in Travel Time Reliability. Institute of Transportation Studies. University of California. Irvine.

Ryu, Seungkyu, Anthony Chen and Yong Seog Kim. 20II. Investigating Travel Time Reliability Measures in Toll Design Problem. Proceedings of the Eastern Asia Society for Transportation Studies, Vol.8, 20II

Small, K. A., Noland, R., Chu, X., Lewis, D., 1999. Valuation of Travel Time Savings and Predictability in Congested Conditions for Highway User Cost Estimation. NCHRP Report Nomor 43I, TRB, National Research Council. Washington, D.C.

Susilawati, Michael AP Taylor and Sekhar VC Somemenahalliaylor. 2010. Travel Time Reliability Measurement for Selected corridors in the Adelaide Metropolitan Area, Journal Of The Eastern Asia Society for Transportation Studies, Vol. 8. 